\title{
A Report on Introduced Amazon Sailfin Catfish, Pterygoplichthys pardalis in Gombak Basin, Selangor, with Notes on Two Body Patterns of the Species
}

\author{
Abdulwakil Olawale Saba ${ }^{1,2}$, Nor Fariza Rasli ${ }^{1}$, Ahmad Ismail ${ }^{1}$, Syaizwan Zahmir \\ Zulkifli $^{1}$, Intan Faraha A. Ghani ${ }^{3}$, Abdullah Halim Muhammad-Rasul ${ }^{4}$ and \\ Mohammad Noor Azmai Amal ${ }^{1 *}$ \\ ${ }^{1}$ Department of Biology, Faculty of Science, Universiti Putra Malaysia, 43400 UPM Serdang, \\ Selangor, Malaysia \\ ${ }^{2}$ School of Agriculture, Lagos State University, 106101 Epe Campus, Lagos, Nigeria \\ ${ }^{3}$ Department of Science and Biotechnology, Faculty of Engineering and Life Sciences, \\ Universiti Selangor, Bestari Jaya Campus, 45600 Bestari Jaya, Selangor, Malaysia \\ ${ }^{4}$ School of Biological Sciences, Universiti Sains Malaysia, 11800 Gelugor, Penang, Malaysia
}

\begin{abstract}
Invasive introduced fish species are well known for their deleterious impacts on aquatic biodiversity and environment. This study provides the first report on the occurrence of introduced Amazon sailfin catfish, Pterygoplichthys pardalis from the Gombak basin, Selangor, Malaysia, where the suckermouth catfish, Hypostomus

ARTICLE INFO

Article history:

Received: 9 July 2020

Accepted: 22 September 2020

Published: 27 November 2020

DOI: https://doi.org/10.47836/pjtas.43.4.19

E-mail addresses:

sabaola@gmail.com (Abdulwakil Olawale Saba)

norfarizarasli@gmail.com (Nor Fariza Rasli)

aismail@upm.edu.my (Ahmad Ismail)

syaizwan@upm.edu.my (Syaizwan Zahmir Zulkifli)

intanfaraha@unisel.edu.my (Intan Faraha A. Ghani)

mrasu187@gmail.com (Abdullah Halim Muhammad-Rasul)

mnamal@upm.edu.my (Mohammad Noor Azmai Amal)

*Corresponding author

plecostomus and vermiculated sailfin catfish, Pterygoplichthys disjunctivus had been previously reported. Besides, selected morphometric and meristic measurements between $P$. pardalis and $P$. disjunctivus from the Pusu River, Gombak basin were compared. Moreover, we also described two body patterns of the $P$. pardalis collected from the river. The body pattern which does not fit entirely with the known characteristics of $P$. pardalis or $P$. disjunctivus is suspected to be a result of hybridization between
\end{abstract}


both species, but deeper study should be conducted to confirm this claim.

Keywords: Biological invasion, conservation, Gombak basin, invasive fish, Klang Valley

\section{INTRODUCTION}

In many countries, fish species belonging to the family Loricariidae have become intentionally or inadvertently introduced into natural habitats, where they have become established (Wu et al., 2011). For example, such introductions have been reported in the Puerto Rico (BunkleyWilliams et al., 1994), Taiwan (Liang et al., 2005), United States (Gibbs et al., 2008), and Bangladesh (Hoosain et al., 2008). In Southeast Asia, introductions of these fishes have been reported in the Philippines (Chávez et al., 2006), Singapore (Page \& Robins, 2006), Vietnam (Levin et al., 2008), Thailand (Chaichana \& Jongphadungkiet, 2012), Indonesia (Qoyyimah et al., 2016), and Malaysia (Khairul-Adha et al., 2013; Samat et al., 2016).

Currently, a total of 17 valid species under genus Pterygoplichthys were reported (Fricke et al., 2020). Some of the species of the genus Pterygoplichthys have now invaded five continents and 21 countries around the world (Orfinger \& Goodding, 2018), and are known for their impacts on economies and the environment. Specifically, fishes of the genus Pterygoplichthys have been reported to reduce native fish populations due to food competition (Hubilla et al., 2008), increase in the water turbidity as a result of the burrowing males (Gibbs et al., 2010), and predate on eggs (Chaichana \& Jongphadungkiet, 2012).

The Amazon sailfin catfish, Pterygoplichthys pardalis is native to the Amazon River basin. However, it has since expanded its range to North America, the Caribbean, and more recently to South Asia (Hossain et al., 2018). Pterygoplichthys pardalis successfully invades new habitats presumably due to its modified scales and strong spines that help to protect it from predation, tolerance to low concentrations of dissolved oxygen, nest construction, parental care, and tolerance to varying levels of salinity (Armbruster \& Page, 2006; Capps et al., 2011; Rueda-Jasso et al., 2013).

The importation of $P$. pardalis into Malaysia has been due to the ornamental fish industry (Khairul-Adha et al., 2013). In Malaysia, $P$. pardalis was previously reported in Langat River, Selangor (Samat et al., 2008), Perak River, Perak (Hashim et al., 2012) and Muar River, Negeri Sembilan (Hasyimah et al., 2013). In this study, we provide the first report on the occurrence of introduced $P$. pardalis in Gombak basin, Selangor, Malaysia. Moreover, we also describe two body patterns of $P$. pardalis collected from the area.

\section{MATERIALS AND METHODS}

The study was conducted at Pusu River, a small tributary of Gombak basin, Selangor, which is located near the International Islamic University, Gombak Campus, Selangor, Malaysia, with the coordinates 
of $3^{\circ} 15^{\prime} 01.5^{\prime \prime} \mathrm{N}, 101^{\circ} 43^{\prime} 45.8^{\prime} \mathrm{E}$ (Figure $1)$. The study area has a river width that ranges between 2.5 to $10.0 \mathrm{~m}$ and is shallow with depth ranging between 0.2 to $1.2 \mathrm{~m}$. The river flows moderately over a sandy substrate with murky waters and low canopy cover, and the riverbank is covered with tall grasses. The Pusu River is located within Klang Valley, an urban area with many aquarium stores. Klang Valley has a population of over 4 million people, and this represents about $16 \%$ of Malaysia's population (Naji et al., 2014). The sampling took place on $24^{\text {th }}$ of February 2020.

Two cast nets, each of which is $150 \mathrm{~cm}$ long, $305 \mathrm{~cm}$ in diameter and $2 \mathrm{~cm}$ of mesh size were used for the fish sampling. In each sampling point, two hours were given for the fish sampling activity. Collected fishes were fixed in $10 \%$ of formalin and then preserved in $70 \%$ of alcohol for long storage. Voucher specimens were deposited in the Museum of Zoology, University Malaya, Kuala Lumpur (UMKL).

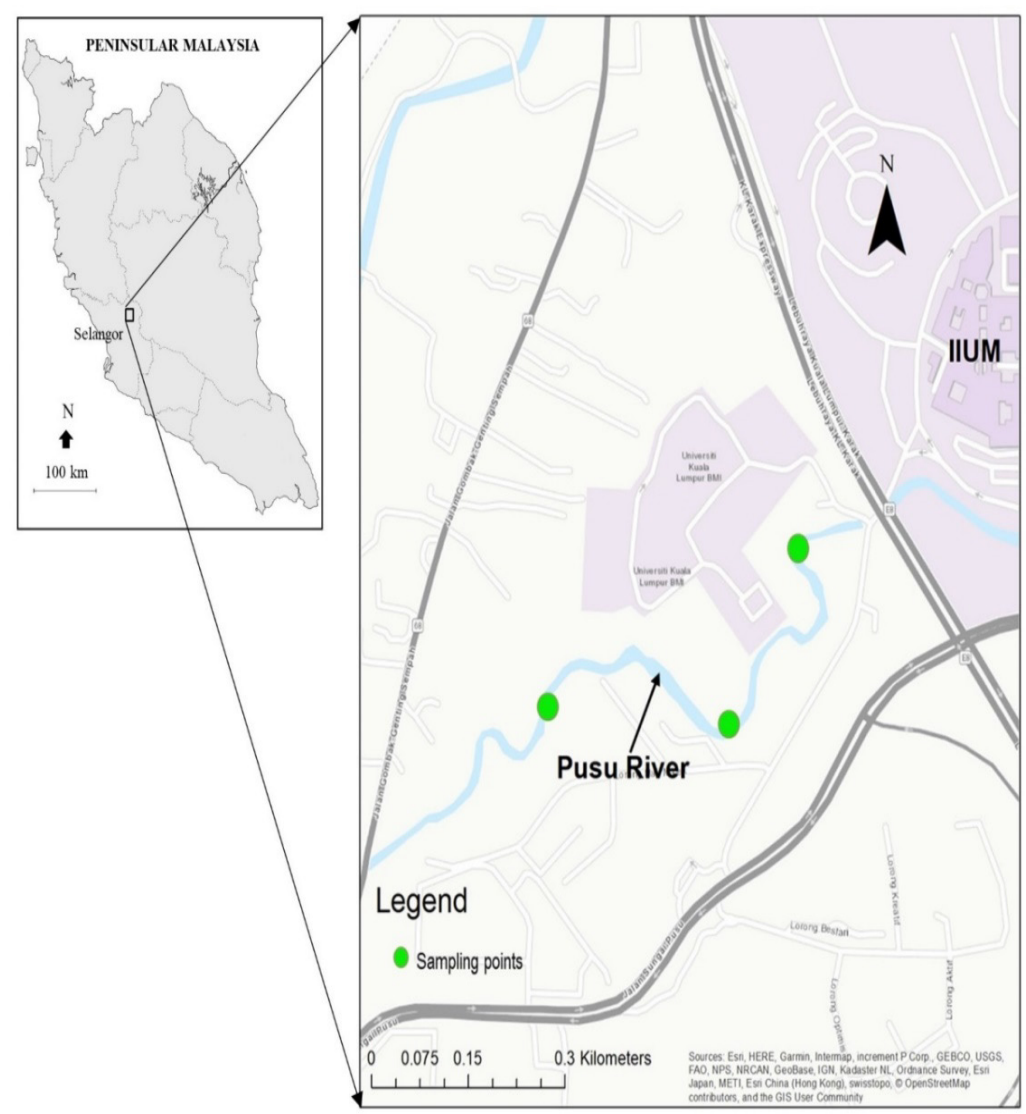

Figure 1. Locations of the occurrence of the Amazon sailfin catfish, Pterygoplichthys pardalis in Pusu River, Gombak basin, Selangor are indicated by green dots. Map was designed using ArcMap, version 10.2 (www.esri.com) 
Selected counts and measurements were made on the left side of the specimens following Boeseman (1968). Distances were measured in millimeters $(\mathrm{mm})$ using dial calipers and were converted to percentages of standard length (SL) or head length (HL). Morphometric measurement of the collected fishes such as head length, dorsal spine length, pectoral spine length, predorsal length, percentage of head length, head depth, snout length, orbital diameter and interorbital distance were compared using one-way ANOVA followed by Tukey's post hoc test. Following dissection, the sex of the fish was easily identifiable since the gonads were easily visible and distinguishable.

Specimens were identified based on keys provided by Armbruster and Page (2006), Page and Robins (2006), as well as Golani and Snovsky (2013). The photos of freshly caught and preserved specimens were also taken for further identification.

\section{RESULTS}

Fish of the genus Pterygoplichthys is mainly identified based on body pattern on the ventral side. Based on the observed coloration and stripe patterns, three body patterns of Pterygoplichthys were found in Pusu River, namely the Amazon sailfin catfish, $P$. pardalis 'type A', P. pardalis 'type B', and the vermiculated sailfin catfish, $P$. disjunctivus. Table 1 summarizes the selected morphometric and meristic measurements for the three types of the Pterygoplichthys found in the study area. Most of the measurements fell within the same range, with the exception of the snout lengths of $P$. pardalis 'type A' that appeared to be significantly $(p<0.05)$ shorter compared to $P$. pardalis 'type B' and $P$. disjunctivus. Thus, coloration and stripe patterns were more useful in differentiating this species.

Pterygoplichthys pardalis was identified by having discrete dark spots on the ventral part of the body. This species has a pattern of uncoalesced dark spots with a light background. Its pectoral fins are stout with rough surfaces and an inferior disk-shaped protrusible mouth, which we named as $P$. pardalis 'type A' (Figure 2). In contrast, $P$. disjunctivus has dark vermiculations on a light background. The vermiculations are mostly continuous with one another, unlike the mostly unconnected spots found in $P$. pardalis (Figure 3).

However, in this study, we also found several specimens of $P$. pardalis that have more discrete and larger spots than the other specimens, and linked to form short chains, which we named as $P$. pardalis 'type B' (Figure 4).

\section{DISCUSSION}

This study presents the first report of the introduced loricariid species, $P$. pardalis in the Gombak basin, Selangor, Malaysia. This finding also has added one more fish species to the list of Fatinizzati et al. (2018), which make the current total number of fish species known to occur in Gombak basin is 35. In Malaysia, P. pardalis was previously reported in Langat River, Selangor (Samat et al., 2008), Perak River, Perak (Hashim et al., 2012), and Muar River, Negeri 
Introduced Amazon Sailfin Catfish

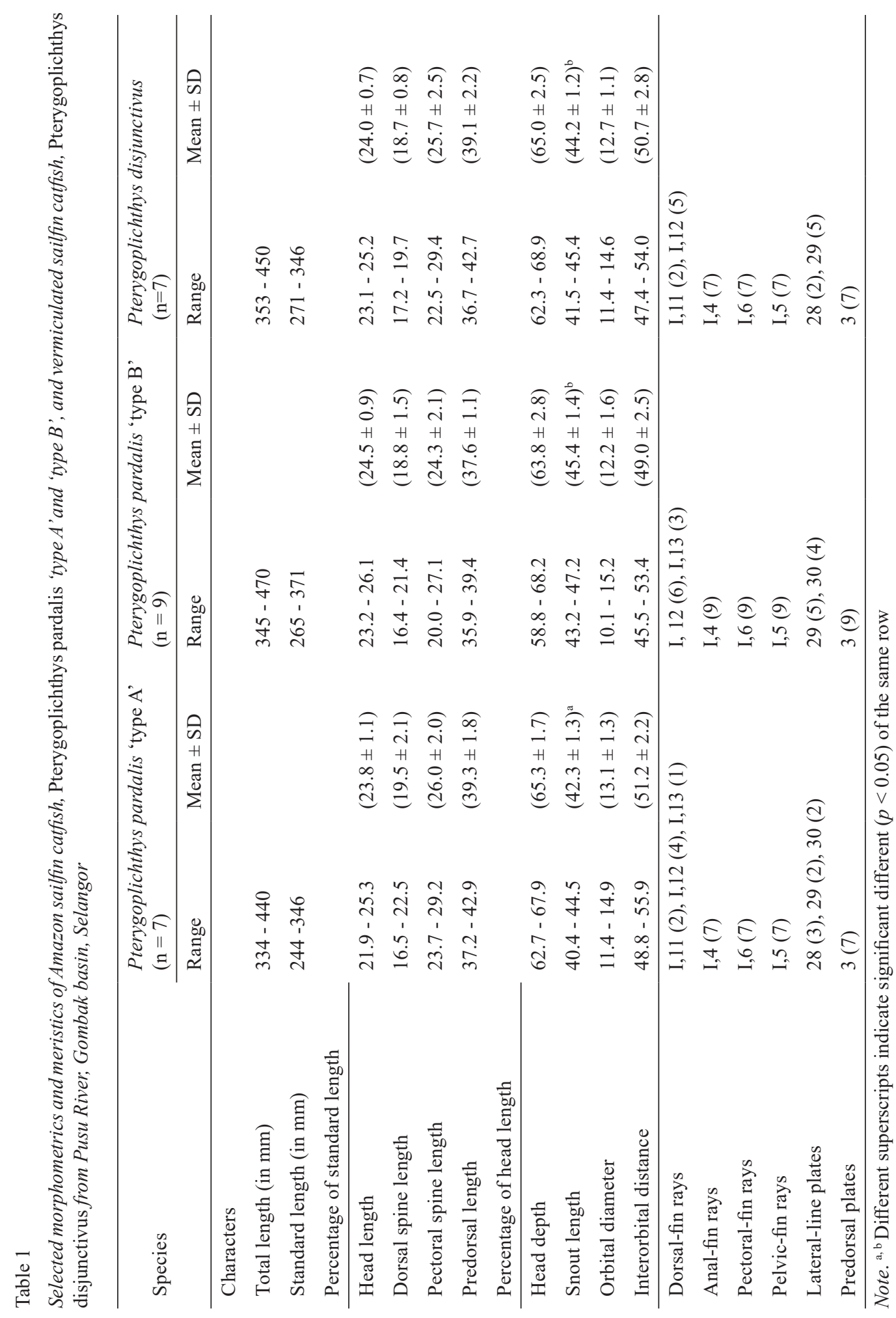

Pertanika J. Trop. Agric. Sci. 43 (4): 693 - 703 (2020) 
Abdulwakil Olawale Saba, Nor Fariza Rasli, Ahmad Ismail, Syaizwan Zahmir Zulkifli, Intan Faraha A. Ghani, Abdullah Halim Muhammad-Rasul and Mohammad Noor Azmai Amal

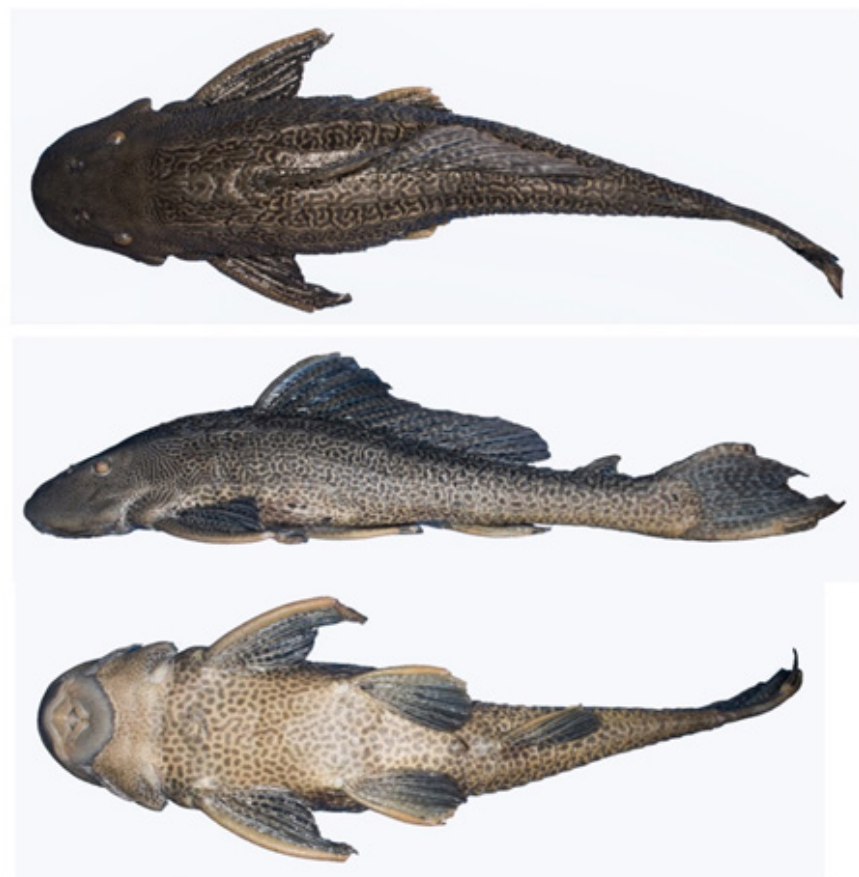

Figure 2. Dorsal, lateral, and ventral views of the Amazon sailfin catfish, Pterygoplichthys pardalis 'type A', UMKL 12834-1, 345.0 mm SL (Photos by Muhammad-Rasul A. H.)

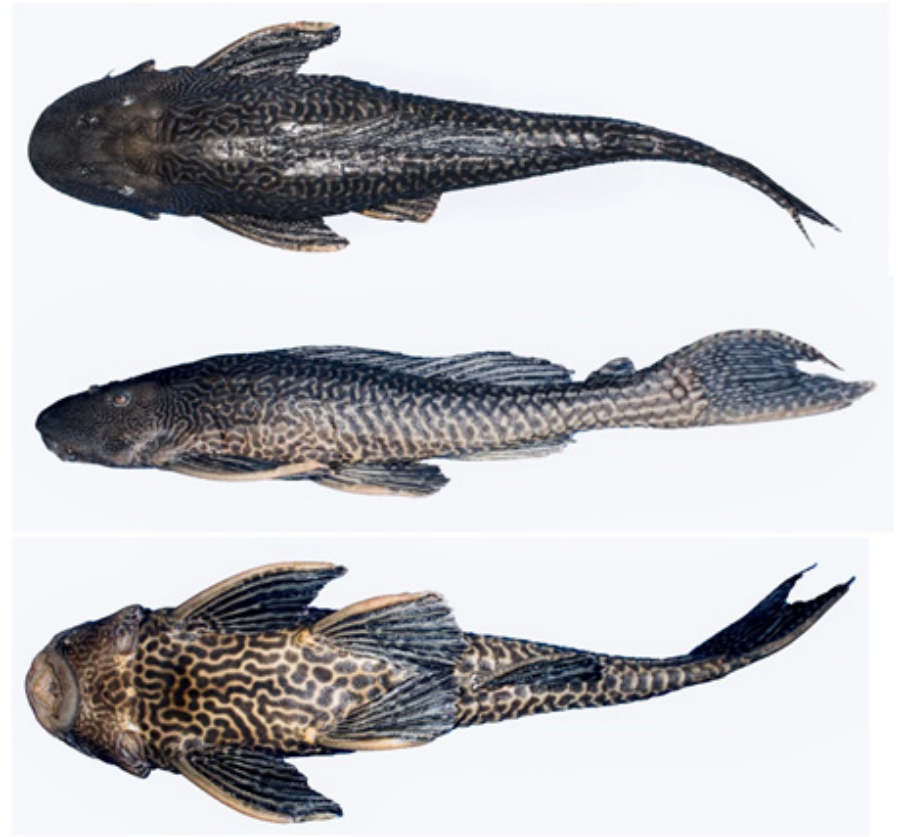

Figure 3. Dorsal, lateral, and ventral views of the vermiculated sailfin catfish, Pterygoplichthys disjunctivus, UMKL 12835-1, 342.0 mm SL (Photos by Muhammad-Rasul A. H.) 

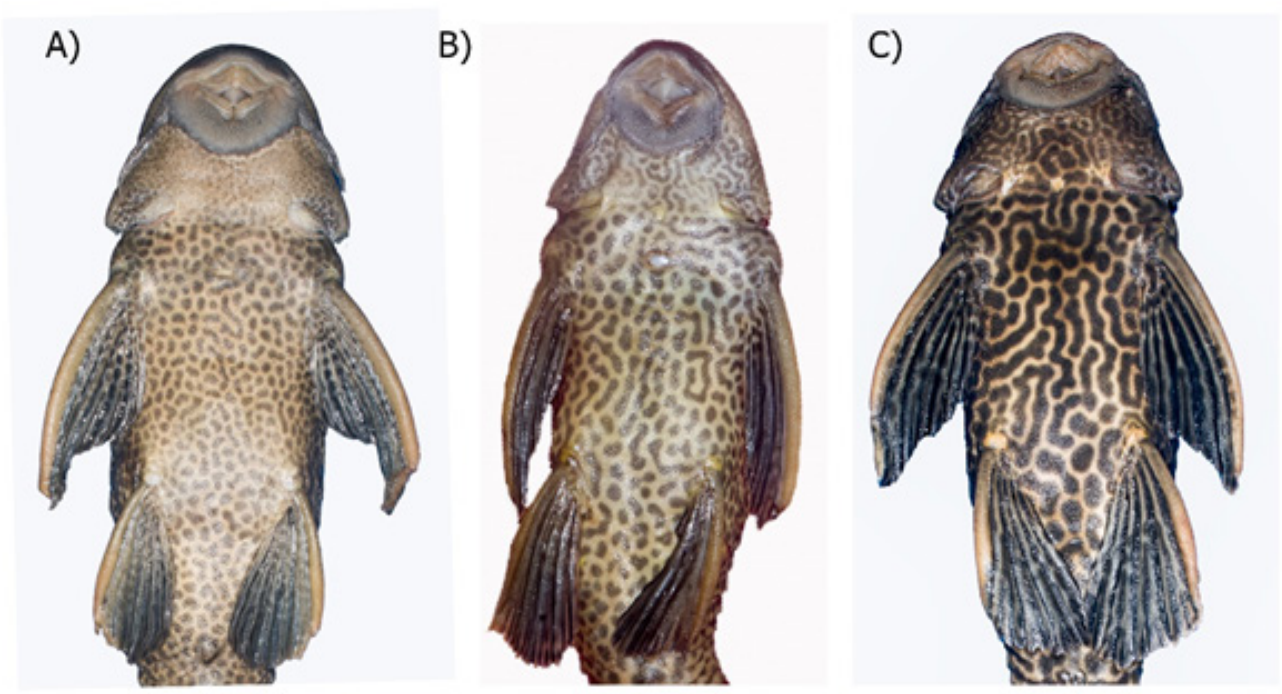

Figure 4. Comparison on the body pattern on the ventral part of Pterygoplichthys spp. from Pusu River, Gombak basin, Selangor. A) Pterygoplichthys pardalis 'type A', B) Pterygoplichthys pardalis 'type B', and C) Pterygoplichthys disjunctivus (Photos by Muhammad-Rasul A. H.)

Sembilan (Hasyimah et al., 2013), while $P$. disjunctivus was reported for Kampar River catchment, Perak (Ng et al., 2018) and Pahang River, Pahang (Mohd-Sukeri et al., 2020).

The occurrences of fish species of the genus Pterygoplichthys have been reported to result in negative impacts, whereas these species continue to flourish. Some of the impacts include a reduction in native fish population due to competition for food, increase in water turbidity due to the effect of the burrowing activities of the males, and predation on the eggs of co-occurring fishes (Chaichana \& Jongphadungkiet, 2012; Gibbs et al., 2010; Hubilla et al., 2008). Loricariid species do not only forage along the bottoms of streams and lakes, but also bury their heads in the substrates and lash their tails occasionally making it possible to shear and uproot aquatic plants, thus reducing the abundance of submerged aquatic vegetation (Global Invasive Species Database [GISD], 2020). Their grazing activities on benthic algae and detritus may also reduce the availability of food and shelter for aquatic insects, which serve as food for other resident fish species (Ozdilek, 2007). In the long run, their activities may lead to bank structure alteration, which may cause erosion, competition with native species, alteration of the aquatic flora, and fishing gear damage (GISD, 2020; Hossain et al., 2018).

Previously, Jalal et al. (2018) reported the occurrence of the suckermouth catfish, 
Hypostomus plecostomus from Pusu River, which we did not find during this study. This may be a result of the very low sampling effort deployed in this study. Meanwhile, Fatinizzati et al. (2018) only found $P$. disjunctivus in Pusu River. Species of the genus Pterygoplichthys are often confused with Hypostomus, from which they can be easily distinguished by having more dorsal fin rays 11-14 dorsal rays (vs. 7 in Hypostomus) (Fatinizzati et al., 2018; Golani \& Snovsky, 2013).

In this study, we suspect that the different body patterns of $P$. pardalis 'type B' may have resulted from hybridization between $P$. pardalis and $P$. disjunctivus, which were both encountered at the same time. However, deeper investigation based on molecular analysis is needed to confirm this claim. Indeed, hybridization ability of different invasive fish species in natural waterbodies could add more to the problems of native fishes in this country. However, in this study, it is glaring that the $P$. pardalis 'type B' body pattern is distinguishable from the typical dark vermiculations on a light background which is obtainable in P. pardalis (Chávez et al., 2006). The morphometric and meristic measurements for the three types of the Pterygoplichthys in this study generally fell within the same range. Thus, coloration and stripe patterns were more useful in differentiating this species.

\section{CONCLUSION}

This study provides the first report on the occurrence of introduced Amazon sailfin catfish, Pterygoplichthys pardalis from the Gombak basin, Selangor. Moreover, we also described two body patterns of the $P$. pardalis collected from the river. The variant which does not fit entirely with the known characteristics of $P$. pardalis or $P$. disjunctivus is suspected to be a result of hybridization between both species, but deeper study should be conducted to confirm this claim.

\section{ACKNOWLEDGEMENT}

Financial support was granted by the Ministry of Higher Education, Malaysia under the Fundamental Research Grant Scheme (FRGS/1/2018/STG03/UPM/02/11).

\section{REFERENCES}

Armbruster, J. W., \& Page, L. M. (2006). Redescription of Pterygoplichthys punctatus and description of a new species of Pterygoplichthys (Siluriformes: Loricariidae). Neotropical Ichthyology, 4(4), 401409. doi: 10.1590/s1679-62252006000400003

Boeseman, M. (1968). The genus Hypostomus Lacépède, 1803, and its Surinam representatives (Siluriformes, Loricariidae). Zoologische Verhandelingen, 99(1), 1-89.

Bunkley-Williams, L., Williams, E. H., Lilystrom, C. G. J., Corujo-Flores, I., Zerbi, A. J., Aliaume, C., \& Churchill, T. N. (1994). The South American sailfin armored catfish Liposarcus multiradiatus (Hancock), a new exotic established in Puerto Rican fresh waters. Caribbean Journal of Science, 30(1), 90-94.

Capps, K. A., Nico, G. L., Mendoza-Carranza, M., Arévalo-Frías, W., Ropicki, A. J., Heilpern, S. A., \& Rodiles-Hernández, R. (2011). Salinity tolerance of nonnative suckermouth catfish (Loricariidae: Pterygoplichthys) in south eastern 
Mexico: Implications for invasion and dispersal. Aquatic Conservation: Marine and Freshwater Ecosystems, 21(6), 528-540. doi: 10.1002/ aqc. 1210

Chaichana, R., \& Jongphadungkiet, S. (2012). Assessment of the invasive catfish Pterygoplichthys pardalis (Castelnau, 1855) in Thailand: Ecological impacts and biological control alternatives. Tropical Zoology, 25(4), 173-182. doi: 10.1080/03946975.2012.738494

Chávez, J. M., Reynaldo, M., Paz, D. L., Manohar, S. K., Pagulayan, R. C., \& Vi, J. R. C. (2006). New Philippine record of South American sailfin catfishes (Pisces: Loricariidae). Zootaxa, 1109(1), 57-68. doi: 10.11646/zootaxa.1109.1.6

Fatinizzati, A. H. N., Zahidah, A. S. N., Rasul, A. H. M., \& Khaironizam, M. Z. (2018). Ichthyofaunal diversity of Sungai Gombak, Selangor, Peninsular Malaysia: Past and current knowledge. Malayan Nature Journal, 70(4), 421-434.

Fricke, R., Eschmeyer, W. N., \& Van der Laan R. (Eds.) (2020). Eschmeyer's catalog of fishes: Genera, species, references. Retrieved January 26, 2020, from http://researcharchive. calacademy.org/research/ichthyology/catalog/ fishcatmain.asp

Gibbs, M. M., Shields, J. H., Lock, D. W., Talmadge, K. M., \& Farell, T. M. (2008). Reproduction in an invasive exotic catfish Pterygoplichthys disjuctivus in Volusia Blue Spring, Florida, USA. Journal of Fish Biology, 73(7), 1562-1572. doi: 10.1111/j.1095-8649.2008.02031.x

Gibbs, M., Futral, T., Mallinger, M., Martin, D., \& Ross, M. (2010). Disturbance of the Florida manatee by an invasive catfish. Southeastern Naturalist, 9(4), 635-648. doi: 10.1656/058.009.0401
Global Invasive Species Database. (2020). Species profile: Pterygoplichthys pardalis. Retrieved January 09, 2020, from http://www.iucngisd.org/ gisd/species.php?sc $=1658$

Golani, D., \& Snovsky, G. (2013). Occurrence of suckermouth armored catfish (Siluriformes, Loricariidae, Pterygoplichthys) in inland waters of Israel. BioInvasions Records, 2(3), 253-256. doi: 10.3391/bir.2013.2.3.13

Hashim, Z. H., Zainuddin, R. Y., Shah, A. S. R. M., Sah, S. A. M., Mohammad, M. S., \& Mansor, M. (2012). Fish checklist of Perak River, Malaysia. Check List, 8(3), 408-413. doi: 10.15560/8.3.408

Hasyimah, N., Syakira, M. H., Mohd-Syahril, M. Z., Samat, A., \& Iwana, I. (2013). Water quality, diversity and distribution of freshwater fishes in Negeri Sembilan. Journal of Academia, 3(1), 10-19.

Hoosain, M. Y., Rahman, M. M., Ahmed, Z. F., Ohtomi, J., \& Islam, A. B. M. S. (2008). First record of South America sailfin catfish Pterygoplichthys multiradiatus in Bangladesh. Journal of Applied Ichthyology, 24(6), 718-720. doi: 10.1111/j.1439-0426.2008.01117.x

Hossain, M. Y., Vadas, R. L., Ruiz-Carus, R., \& Galib, S. M. (2018). Amazon sailfin catfish Pterygoplichthys pardalis (Loricariidae) in Bangladesh: A critical review of its invasive threat to native and endemic aquatic species. Fishes, 3(1), 14. doi: 10.3390/fishes3010014

Hubilla, M., Kis, F., \& Primavera, J. (2008). Janitor fish Pterygoplichthys disjunctivus in the Agusan Marsh: A threat to freshwater biodiversity. Journal of Environmental Science and Management, 10(1), 10-23.

Jalal, K. C. A., Alifah, F. K., Faizul, H. N. N., Mamun, A. A., Kader, M. A., \& Ashraf, M. A. (2018). 
Diversity and community composition of fishes in the Pusu River (Gombak, Malaysia). Journal of Coastal Research, 82(10082), 150-155. doi: 10.2112/si82-021.1

Khairul-Adha, R., Yuzine, E., \& Aziz, A. (2013). The influence of alien fish species on native fish community structure in Malaysian waters. Kuroshio Science, 7(1), 81-93.

Levin, B. A., Phuong, P. H., \& Pavlov, D. S. (2008). Discovery of the Amazon sailfin catfish Pterygoplichthys pardalis (Castelnau, 1855) (Teleostei: Loricariidae) in Vietnam. Journal of Applied Ichthyology, 24(6), 715-717. doi: 10.1111/j.1439-0426.2008.01185.x

Liang, S. H., Wu, H. P. L., \& Shied, B. S. (2005). Size structure, reproductive phenology and sex ratio of an exotic sailfish catfish (Liposarcus multiradiatus) in the Kaoping river of southern Taiwan. Zoological Studies, 44(2), 252-259.

Mohd-Sukeri, N. F., Zulkafli, A. R., Saba, A. O., Muhammad-Rasul, A. H., \& Amal, M. N. A. (2020). The influences of water quality on fish occurrences in Kuala Mai, Pahang River and Ulu Tembeling, Tembeling River, Pahang, Malaysia. Pertanika Journal of Tropical Agricultural Science, 43(2), 163-182.

Naji, A., Ismail, A., Kamrani, E., \& Sohrabi, T. (2014). Correlation of MT levels in livers and gills with heavy metals in wild tilapia (Oreochromis mossambicus) from the Klang River, Malaysia. Bulletin of Environmental Contamination and Toxicology, 92(6), 674-679. doi: 10.1007/ s00128-014-1243-4

Ng, C. K. C., Ooi, P. A. C., Wong, W. L., \& Khoo, G. (2018). Ichthyofauna checklist (Chordata: Actinopterygii) for indicating water quality in Kampar River catchment, Malaysia. Biodiversitas, 19(6), 2252-2274. doi: 10.13057/ biodiv/d190634
Orfinger, A. B., \& Goodding, D. D. (2018). The global invasion of the suckermouth armored catfish genus Pterygoplichthys (Siluriformes: Loricariidae): Annotated list of species, distributional summary, and assessment of impact. Zoological Studies, 57, e7. doi:_10.6620/ ZS.2018.57-07

Ozdilek, S. Y. (2007). Possible threat for Middle East inland water: An exotic and invasive species, Pterygoplichthys disjunctivus (Weber, 1991) in Asi River, Turkey (Pisces: Loricariidae). Journal of Fisheries and Aquatic Sciences, 24(3-4), 303-306.

Page, L. M., \& Robins, R. H. (2006). Identification of sailfin catfishes (Teleostei: Loricariidae) in southeastern Asia. The Raffles Bulletin of Zoology, 54(2), 455-457.

Qoyyimah, F. D., Elfidasari, D., \& Fahmi, M. R. (2016). Identification of suckermouth armored catfish (Loricariidae), based on abdominal pattern, in Ciliwung River. Jurnal Biologi, 20(1), 40-43.

Rueda-Jasso, R. A., Campos-Mendoza, A., ArreguínSánchez, F., Díaz-Pardo, E., \& MartínezPalacios, C. A. (2013). The biological and reproductive parameters of the invasive armored catfish Pterygoplichthys disjunctivus from Adolfo López Mateos El Infiernillo Reservoir, Michoacán-Guerrero, Mexico. Revista Mexicana de Biodiversidad, 84(1), 318-326. doi: 10.7550/ rmb.26091

Samat, A., Shukor, M. N., Mazlan, A. G., Arshad, A., \& Fatimah, M. Y. (2008). Lengthweight relationship and condition factor of Pterygoplichthys pardalis (Pisces: Loricariidae) in Malaysia Peninsula. Research Journal of Fisheries and Hydrobiology, 3(2), 48-53.

Samat, A., Yusoff, F. M., Arshad, A., Ghaffar, M. A., Nor, S. M., Magalhaes, A. L. B., \& Das, 
S. K. (2016). Reproductive biology of the introduced sailfin catfish Pterygoplichthys pardalis (Pisces: Loricariidae) in Peninsular Malaysia. Indian Journal of Fisheries, 63(1), 35-41. doi: 10.21077/ijf.2016.63.1.44937-05

Wu, L. W., Liu, C. C., \& Lin, S. M. (2011). Identification of exotic sailfin catfish species (Pterygoplichthys, Loricariidae) in Taiwan based on morphology and mtDNA sequences. Zoological Studies, 50(2), 235-246. 
